\title{
Purification and characterization of an antifungal protein from Bacillus subtilis XL62 isolated in Vietnam
}

\author{
Thi Tuyen Do ${ }^{\mathrm{a}, \mathrm{b}, *}$, Thanh Hoang Le ${ }^{\mathrm{a}}$, Thi Thao Nguyen ${ }^{\mathrm{a}}$, Sy Le Thanh Nguyen ${ }^{\mathrm{a}}$, Thi Mai Anh Dao \\ ${ }^{a}$ Institute of Biotechnology, Vietnam Academy of Science and Technology, Hanoi, Vietnam \\ b Graduate University of Science and Technology, Hanoi, Vietnam \\ c Department of Biochemistry, Hanoi University of Pharmacy, Hanoi, Vietnam
}

*Corresponding author, e-mail: dttuyen@ibt.ac.vn

Received 8 May 2017

Accepted 6 Oct 2017

\begin{abstract}
Bacillus subtilis is considered as a potential antagonist for fungal control due to its ability to produce a wide range of antibiotics. This study determines the antifungal activity of the native B. subtilis XL62 and we purify, identify, and characterize the antifungal protein. The results show that the growth inhibitory activity to Fusarium oxysporum and Rhizoctonia solani of the crude supernatant of B. subtilis XL62 was proportional to the concentration. At the highest concentration (50\%), the growth inhibition reached $90 \%$ and $100 \%$ for $F$ oxysporum, and $R$. solani, respectively. Furthermore, the crude supernatant of B. subtilis XL62 also inhibited the germination and growth of $R$. solani. The growth of sclerotia was almost completely inhibited at the concentration of $20 \%$ and the ability to germinate was lost at the concentration of 50\%. Antifungal proteins were isolated from the crude bacterial supernatant using ammonium sulphate precipitation followed by passage over DEAE-cellulose and Biogel P100 columns. The purified protein had an apparent molecular mass of $22 \mathrm{kDa}$. Its antifungal activity was retained even at $100^{\circ} \mathrm{C}$, for $60 \mathrm{~min}$ and after treatment with proteinase $\mathrm{K}(0.5-2.5 \mu \mathrm{g} / \mathrm{ml})$. The results of protein identification using a MALDI-TOF/TOF mass spectrometer suggest that the purified protein is indeed a chitin-binding protein.
\end{abstract}

KEYWORDS: Fusarium oxysporum, Rhizoctonia solani

\section{INTRODUCTION}

Plant pathogenic fungi are among the most important biotic agent causing serious losses and damages to agriculture products. As a result, fungal diseases have major economic impacts in the agriculture industry. Chemical fungicides are so far the most popular choice for plant diseases. However, despite the effectiveness of the conventional chemical fungicides, concerns about the environmental contamination and human health risks associated with fungicide residues have been raised owing to their extremely high toxicity. Protection of crops against their fungal enemies using bacterial antagonists is, therefore, recently became an attractive alternative approach to facilitate sustainable agriculture in many countries. Three well-known and widely used bacterial biocontrol agents are Bacillus spp., Pseudomonas spp., and Streptomyces spp. Among these, Bacillus spp. appears to be the most potential candidates. Bacillus spp. offer several advantages over other organisms since they can form endospores and can tolerate extreme $\mathrm{pH}$, temperature, and osmotic conditions ${ }^{1}$. Furthermore, they produce a diverse array of antifungal compounds, which range from small peptides, such as iturin ${ }^{2,3}$, surfactin ${ }^{4,5}$, fengymycin, bacilysin ${ }^{6}$, bacillomycin $^{7}$, mycosubtilin $^{8}$, and mycobacillin ${ }^{9,10}$, to volatile metabolites ${ }^{11,12}$.

To find out novel agro-ecological crop protection weapons, one hundred and forty-seven Bacillus strains isolated from trunks, leaves, roots, and soil from different provinces in Vietnam were screened for antifungal activity. Using the method of Weller ${ }^{13}, B$. subtilis XL62 was selected for further study. This bacterial strain was identified based on its morphological, biochemical, and physiological characteristics, and by $16 \mathrm{~S}$ rDNA analysis (GenBank by code No. FJ465166).

The present study was aimed at determining the antifungal activity of the crude supernatant from $B$. subtilis XL62 against $R$. solani and F. oxysporum, two soil phytopathogenic fungi that are widespread in Vietnam. The antifungal protein was purified and characterized with respect to thermal stability and proteolytic resistance to proteinase $\mathrm{K}$. 


\section{MATERIALS AND METHODS}

\section{Microorganisms}

The F. oxysporum and R. solani strains were provided by the Plant Diseases Division at the Institute of Plant Protection, Tu Liem, Hanoi. B. subtilis XL62 was supplied by the Department of Enzyme Biotechnology at the Institute of Biotechnology, Vietnam Academy of Science and Technology. B. subtilis XL62 was grown in NYD medium ( $\mathrm{pH} 7.5)$, which comprised glucose $(10 \mathrm{~g} / 1)$, beef extract $(8 \mathrm{~g} / 1)$, and yeast extract $(5 \mathrm{~g} / \mathrm{l})$.

\section{Chemicals}

$\mathrm{NaCl}$ and D-glucose were purchased from Merck (Darmstadt, Germany). Minisart membranes and agar were purchased from Biotech (Vietnam). DEAE-cellulose, Biogel P100, Trisbase and Bovine serum albumin (BSA) were supplied Sigma-Aldrich (St. Louis, MO, USA). $\mathrm{NaHPO}_{4}, \mathrm{Na}_{2} \mathrm{HPO}_{4}$, meat extract, and yeast extract were purchased from BioBasic Inc. (Ontario, Canada).

\section{Antifungal activity of the crude bacterial supernatant determination}

The crude supernatant from $B$. subtilis XL62 was obtained by centrifuging the bacterial culture at $11000 \mathrm{~g}$ for $10 \mathrm{~min}$. The antifungal activity against F. oxysporum and $R$. solani of this crude supernatant was determined using the method of Huber ${ }^{14}$. Different amounts of the crude supernatant were added to potato dextrose agar (PDA) at $55^{\circ} \mathrm{C}$, mixed well, and poured into Petri dishes $(90 \times 15 \mathrm{~mm})$. The final concentration of the crude supernatant was $5 \%$, $10 \%, 20 \%$, or $50 \%$. Finally, an $R$. solani sclerotia or a mycelial plug $(0.5 \mathrm{~cm}$ diameter) from 4-day-old cultures of $F$. oxysporum or $R$. solani was placed in the centre of the PDA plates and incubated at $30^{\circ} \mathrm{C}$ for 5 days. The PDA plates without crude bacterial supernatant were used as negative controls. The growth of $F$. oxysporum and $R$. solani was determined by measuring colony diameter (in $\mathrm{mm}$ ).

The ability of the crude supernatants to inhibit fungal growth was calculated as $I=\left(S_{\text {control }}-\right.$ $\left.S_{\text {samples }}\right) / S_{\text {control }}$, where $S_{\text {control }}$ is the area of the non-supernatant-containing PDA plates occupied by colonies and $S_{\text {samples }}$ is the area of the supernatantcontaining PDA plates occupied by colonies. All the tests were conducted in triplicate.

\section{Antifungal protein purification}

The bacterial culture was centrifuged at $11000 \mathrm{~g}$ for $10 \mathrm{~min}$. Ammonium sulphate (30-70\% satu- ration) was then slowly added to $200 \mathrm{ml}$ of crude protein solution with constant stirring. The mixture was left overnight and then centrifuged at $12500 \mathrm{rpm}$ for $10 \mathrm{~min}$. The supernatant was then carefully decanted, and the precipitate was re-dissolved in $0.02 \mathrm{M}$ phosphate buffer ( $\mathrm{pH}$ 6.8) and dialysed to remove the salt. The dialysed fraction $(6 \mathrm{ml})$ was then applied to a DEAE-cellulose column $(2.6 \times 6 \mathrm{~cm})$ pre-equilibrated with $0.02 \mathrm{M}$ phosphate buffer ( $\mathrm{pH} \mathrm{6.8)} \mathrm{at} \mathrm{a} \mathrm{flow} \mathrm{rate} \mathrm{of} 25 \mathrm{ml} / \mathrm{h}$ until the OD $280 \mathrm{~nm}$ was $<0.01$. The column was then eluted with $0.02 \mathrm{M}$ phosphate buffer ( $\mathrm{pH}$ 6.8) containing $1 \mathrm{M} \mathrm{NaCl}$. The eluted fractions of $1.5 \mathrm{ml}$ were collected (27 fractions). The antifungal activity of each purified fraction was tested against $F$. oxysporum and $R$. solani. Fractions with strong antifungal activity were continuously purified on a Biogel P100 column. The column was then eluted with $0.02 \mathrm{M}$ phosphate buffer ( $\mathrm{pH}$ 6.8) at a flow rate of $25 \mathrm{ml} / \mathrm{h}$ and fractions of $1.5 \mathrm{ml}$ were collected. The antifungal activity of the purified fractions was once again tested against the two above pathogenic fungi. All purification steps were carried out at $4{ }^{\circ} \mathrm{C}$ unless specified otherwise.

\section{Gel electrophoresis and protein concentration measurement}

The purified antifungal protein isolated from $B$. subtilis XL62 was examined in $12 \%(\mathrm{w} / \mathrm{v})$ SDS polyacrylamide gels ${ }^{15}$ using Biometra equipment (Göttingen, Germany). Separated proteins were stained with $0.1 \%(\mathrm{w} / \mathrm{v}) \mathrm{AgNO}_{3}{ }^{16}$. Protein concentrations were determined using the Bradford method, with BSA as the standard ${ }^{17}$.

\section{Determination of antifungal activity of purified protein}

The antifungal activity of the purified protein was determined using the agar-disk diffusion method. At first, a mycelial plug from 4-day-old cultures of F. oxysporum or $R$. solani was placed in the centre of each $0.1 \%$ ampicillin containing PDA plate. Next, a sterile filter disk with a diameter of $0.5 \mathrm{~cm}$ (Whatman paper No. 3) soaked with $15 \mu l$ of purified protein was placed on the surface of the plates. Negative control disks were soaked with $15 \mu$ l of $20 \mathrm{mM}$ $\mathrm{Na}_{3} \mathrm{PO}_{4}$ buffer $(\mathrm{pH}$ 6.8). These agar plates were then incubated at $30^{\circ} \mathrm{C}$ for $3-5$ days (Incubator, Sanyo, Japan) and the diameters of inhibition zones around the disks were measured. All the tests were conducted in triplicate.

To test for purification and characterization of the antifungal protein, ampicillin $(0.1 \%)$ was added 
to Petri plates $(90 \times 15 \mathrm{~mm})$ containing $10 \mathrm{ml}$ of PDA, and filter papers $(0.5 \mathrm{~cm}$ in diameter $)$ presoaked with $15 \mu \mathrm{l}$ of the purified protein were placed on the surface. The agar plates were then incubated at $30^{\circ} \mathrm{C}$ for $3-5$ days (Incubator, Sanyo, Japan). Filter papers soaked in $0.02 \mathrm{M}$ phosphate buffer (pH 6.8) were used as the control.

Thermal stability and proteolytic resistance to proteinase $\mathrm{K}$ of antifungal protein

The thermal stability of the antifungal protein was determined by incubating the purified protein $(20 \mu \mathrm{l})$ at $80^{\circ} \mathrm{C}$ for $5-60 \mathrm{~min}$ or at $100^{\circ} \mathrm{C}$ for $60 \mathrm{~min}$. Antifungal activity was then determined as described above. The proteolytic resistance to proteinase $\mathrm{K}$ of the antifungal protein was determined by incubating the purified protein $(20 \mu \mathrm{l})$ with $0.5-$ $2.5 \mu \mathrm{g} / \mu \mathrm{l}$ proteinase $\mathrm{K}$ at $37^{\circ} \mathrm{C}$ for $60 \mathrm{~min}$ prior to the measurement of the antifungal activity.

\section{Protein identification}

The purified antifungal protein was characterized using MALDI-TOF MS. The predicted protein was trypsin digested and peptides extracted according to standard techniques ${ }^{18}$. Peptides were analysed by MALDI-TOF/TOF mass spectrometer using a 5800 Proteomics Analyser (AB Sciex). Spectra were analysed to identify proteins of interest using Mascot sequence matching software (Matrix Science) with MSPnr100 Database. Peptide fragments showing ion scores $>59$ were identified uniquely or high similarly $(\mathrm{p}<0.01)$.

\section{Statistical analysis}

All measurements were carried out in triplicate. The means were presented as averages of the experiments.

\section{RESULTS}

\section{Antifungal activity of the crude supernatant from B. subtilis XL62}

Five different concentrations of crude supernatant $(0 \%, 5 \%, 10 \%, 20 \%$, and $50 \%)$ of B. subtilis XL62 were tested for their antifungal activity against $F$. oxysporum and $R$. solani. using the method of Huber as described above.

The results (Table 1 , Table 2 ) show that the crude supernatant of $B$. subtilis XL62 has a significant antifungal activity on both fungal pathogens. At the concentration of $5 \%$ of crude supernatant of $B$. subtilis XL62, the growth inhibition reached about $62 \%$ and $22 \%$ for F. oxysporum and R. solani,
Table 1 Effect of a crude supernatant (c.s.) from B. subtilis XL62 on the growth of F. oxysporum.

\begin{tabular}{lccc}
\hline $\begin{array}{l}\text { Conc. of } \\
\text { c.s. (\%) }\end{array}$ & $\begin{array}{c}\text { Fung. growth } \\
(\varnothing: \mathrm{cm})\end{array}$ & $\begin{array}{c}\text { Inhibitory } \\
\text { activity (\%) }\end{array}$ & $\begin{array}{c}\text { Colony } \\
\text { morphology }\end{array}$ \\
\hline 0 & $7.8 \pm 0.3$ & 0.0 & $\mathrm{CY}^{\dagger}$, light purple \\
5 & $4.8 \pm 0.1$ & 62.1 & $\mathrm{CY}^{\dagger}$, more purple \\
10 & $4.5 \pm 0.1$ & 66.7 & $\mathrm{CY}^{\dagger}$, more purple \\
20 & $3.8 \pm 0.2$ & 76.3 & $\mathrm{CY}^{\dagger}$, dark purple \\
50 & $2.5 \pm 0.1$ & 89.7 & $\mathrm{CY}^{\dagger}$, dark purple \\
\hline
\end{tabular}

* After $120 \mathrm{~h}$; ${ }^{\dagger}$ cotton yarn.

Table 2 Effect of a crude supernatant (c.s.) from B. subtilis XL62 on the growth of $R$. solani mycelia.

\begin{tabular}{lccc}
\hline $\begin{array}{l}\text { Conc. of } \\
\text { c.s. }(\%)\end{array}$ & $\begin{array}{c}\text { Fung. growth } \\
(\varnothing: \mathrm{cm})\end{array}$ & $\begin{array}{c}\text { Inhibitory } \\
\text { activity (\%) }\end{array}$ & $\begin{array}{c}\text { Colony } \\
\text { morphology }\end{array}$ \\
\hline 0 & $8.5 \pm 0.2$ & 0.0 & $\mathrm{CY}^{\dagger}$, white \\
5 & $7.5 \pm 0.2$ & 22.2 & $\mathrm{CY}^{\dagger}$, white \\
10 & $5.0 \pm 0.3$ & 65.4 & $\mathrm{CY}^{\dagger}$, white \\
20 & $2.0 \pm 0.1$ & 94.5 & $\mathrm{CY}^{\dagger}$, white \\
50 & $\leqslant 0.50 \pm 0.01$ & 100.0 & Withered \\
\hline
\end{tabular}

*After 72 h; ${ }^{\dagger}$ cotton yarn.

respectively. The antifungal activity of the crude supernatant of $B$. subtilis XL62 was proportional to the concentration. At a concentration of $5 \%$, the crude supernatant inhibited the growth of $R$. solani by only about $20 \%$, but at a concentration of $10 \%$ this inhibitory activity increased up to $65 \%$ and reach $94 \%$ at a concentration of $20 \%$. The increase in inhibitory activity against $R$. solani occurred over a narrow range of concentrations, but over a little wider range for $F$. oxysporum. At the highest concentration tested (50\%), the growth inhibition reached $100 \%$ for $R$. solani but only about $89 \%$ for F. oxysporum. A similar effect was noted when the effect of the crude supernatant on the germination and growth of $R$. solani sclerotia was examined (Table 3).

Table 3 Effect of a crude supernatant (c.s.) from B. subtilis XL62 on the growth of $R$. solani sclerotia.

\begin{tabular}{lccc}
\hline $\begin{array}{l}\text { Conc. of } \\
\text { c.s. }(\%)\end{array}$ & $\begin{array}{c}\text { Fung. growth } \\
(\varnothing: \mathrm{cm})\end{array}$ & $\begin{array}{c}\text { \% versus } \\
\text { antag. vol. }\end{array}$ & $\begin{array}{c}\text { Mycelia } \\
\text { morphology }\end{array}$ \\
\hline 0 & $8.5 \pm 0.2$ & 0.0 & $\mathrm{CY}^{\dagger}$, white \\
5 & $5.1 \pm 0.2$ & 64.0 & $\mathrm{CY}^{\dagger}$, white \\
10 & $2.0 \pm 0.1$ & 94.5 & $\mathrm{CY}^{\dagger}$, white \\
20 & $1.0 \pm 0.1$ & 98.6 & $\mathrm{CY}^{\dagger}$, white \\
50 & $\leqslant 0.10 \pm 0.01$ & 100.0 & Withered \\
\hline
\end{tabular}

" After $72 \mathrm{~h}$; *antagonist volume; ${ }^{\dagger}$ cotton yarn. 


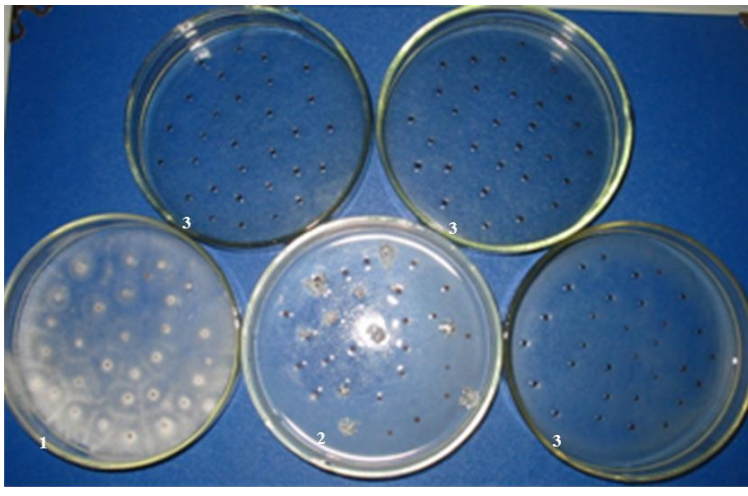

Fig. 1 Testing of the long-term effect of the supernatant on the germination of $R$. solani sclerotia (1-3: sample $R$. solani cultured on PDA medium containing 5\%, 10\% and $50 \%$ crude supernatant and re-cultured the mycelia on PDA plates without crude supernatant.

When grown on PDA medium containing 5\%, $10 \%$, or $20 \%$ crude supernatant, $R$. solani sclerotia were still able to germinate (although growth was strongly inhibited). The growth of sclerotia was inhibited by more than $60 \%$ at a supernatant concentration of $5 \%$ and by over $90 \%$ at a concentration of $10 \%$. Growth of sclerotia was almost completely inhibited at a concentration of $20 \%$. These results suggest that the inhibitory effect of the crude supernatant against $R$. solani may depend on the age of the mycelium. In particular, this fungal strain lost the ability to germinate at a supernatant concentration of $50 \%$.

To test the long-term effect of the supernatant, we took $R$. solani cultured on PDA medium containing $5 \%, 10 \%$ and $50 \%$ crude supernatant and recultured the mycelia on PDA plates without crude supernatant. The results showed that $R$. solani was unable to restore growth. Hence the crude supernatant of $B$. subtilis XL62 at a concentration of $50 \%$ was able to prevent the growth of $R$. solani fibres (Fig. 1).

The crude supernatant also showed different effects on colony morphology. On PDA plates, the amount of synthetic pigment produced by $F$ oxysporum increased in line with the increase in supernatant concentration (Table 1). However, the inhibitory effect on mycelia of $R$. solani was only observed at a concentration of $50 \%$. At this concentration, the normal mycelium morphology of $R$. solani was lost.
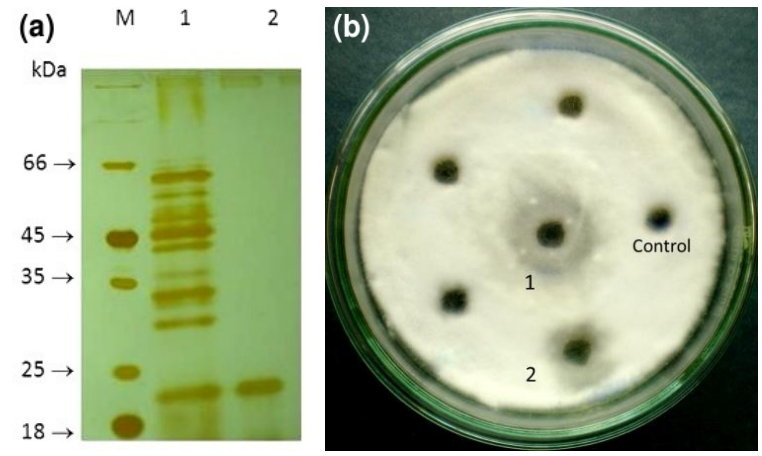

Fig. 2 (a) Protein profile on SDS-PAGE of the crude supernatant (Lane 1), fractions from peak 1 after passage through the Biogel P100 column (Lane 2), M: molecular mass of standard proteins (Fermentas, Thermo Fisher Scientific Inc., Waltham, USA); (b) anti-F. oxysporum activity of the purified protein (control: $20 \mathrm{mM} \mathrm{Na}_{3} \mathrm{PO}_{4}$ buffer, pH 6.8 ; 1 : the crude supernatant; 2 : the purified protein from peak 1 ).

\section{Purification and characterization of antifungal protein}

After $120 \mathrm{~h}$ of cultivation, the crude supernatant of $B$. subtilis XL62 was purified by addition of 30 $-70 \%$ ammonium sulphate, followed by passage over a DEAE-cellulose column. Three range of fractions containing high protein concentration were observed (corresponding to peaks 1, 2, and 3). These fractions were tested for antifungal activity against $F$. oxysporum and all were positive (data not shown). Fractions 5-11 from peak 1 were then mixed and passed over a Biogel P100 column. The purity and relative molecular mass of the proteins were assessed by $12 \%$ polyacrylamide gel electrophoresis with Fermentas protein standards, followed by silver staining. A protein of $\sim 22 \mathrm{kDa}$ was observed (Fig. 2a) and the yield of the purification process was $12 \%$ (Table 4), and exhibited antifungal activity for $F$. oxysporum (Fig. 2b, Fig. 3).

The purified protein was then characterized by MALDI-TOF mass spectrometry. Peptide fragments showing ion scores above 59 identified uniquely

Table 4 The yield of antifungal protein purification from B. subtilis XL62.

\begin{tabular}{lcc}
\hline Purification steps & Total protein $(\mathrm{mg})$ & Yield (\%) \\
\hline Precipitated protein & 3.52 & 100 \\
DEAE-cellulose & 1.44 & 40.9 \\
Biogel P100 & 0.42 & 11.9 \\
\hline
\end{tabular}



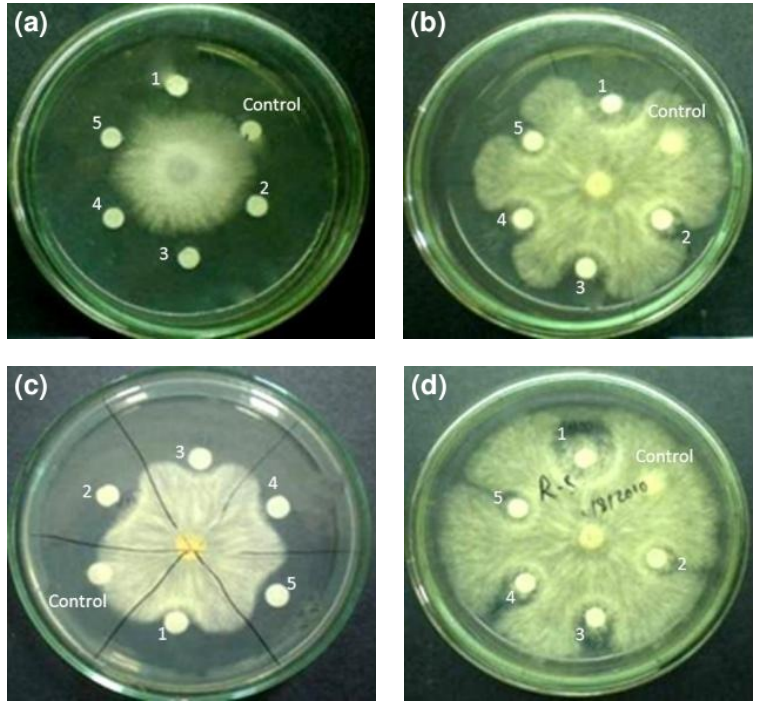

Fig. 3 Antifungal activity against $F$. oxysporum and $R$. solani of the purified protein. The growth inhibition of (b,d) R. solani and (a,c) F. oxysporum by the purified protein after (a,b) 3 days or (c,d) 5 days of exposure. Control: $15 \mu \mathrm{l}$ of $20 \mathrm{mM} \mathrm{Na}_{3} \mathrm{PO}_{4}$ buffer, $\mathrm{pH}$ 6.8; 1 : crude supernatant; 2-5: fractions after passage through the Biogel P 100 column.

Table 5 Peptides exceeding the identity threshold.

\begin{tabular}{lcrrl}
\hline Q. $^{\text {a }}$ & Obs. $^{\text {b }}$ & P.M. $^{\text {c }}$ & S. $^{\text {d }}$ & Peptide sequence \\
\hline 151 & 450.234 & 898.451 & 62 & ADTNLTHK \\
223 & 521.268 & 1040.504 & 67 & GFPAAGPPDGR \\
312 & 587.820 & 1173.614 & 64 & QTLGWTAAAQK \\
491 & 795.401 & 1588.773 & 97 & YGSVIDNPQSVEGPK \\
492 & 795.401 & 1588.773 & 99 & YGSVIDNPQSVEGPK \\
522 & 825.416 & 1648.806 & 146 & IASANGGSGQIDFGLDK \\
527 & 830.900 & 1659.774 & 106 & DEFELIGTVNHDGSK \\
669 & 881.102 & 2640.282 & 141 & IASANGGSGQIDF \\
& & & & GLDKQTADYWVK
\end{tabular}

${ }^{a}$ Query; ${ }^{b}$ observed; cpeptide mass; ${ }^{\mathrm{d}}$ score.

or high similarly with $\mathrm{p}<0.01$. These peptides were $100 \%$ identical to corresponding fragments of the chitin-binding protein (Table 5; Fig. 4). Chitin binding protein from Bacillus (Accession number: WP_003154023) has 206 acid amine containing chitin-bind-3 region such as "Chitin binding domain; pfam03067" from acid amine position 28202 with a relative molecular mass of $22230 \mathrm{Da}$.

\section{Characterization of purified antifungal protein}

The effect of temperature on the purified antifungal protein was studied at $80^{\circ} \mathrm{C}$ for $5-60 \mathrm{~min}$ and

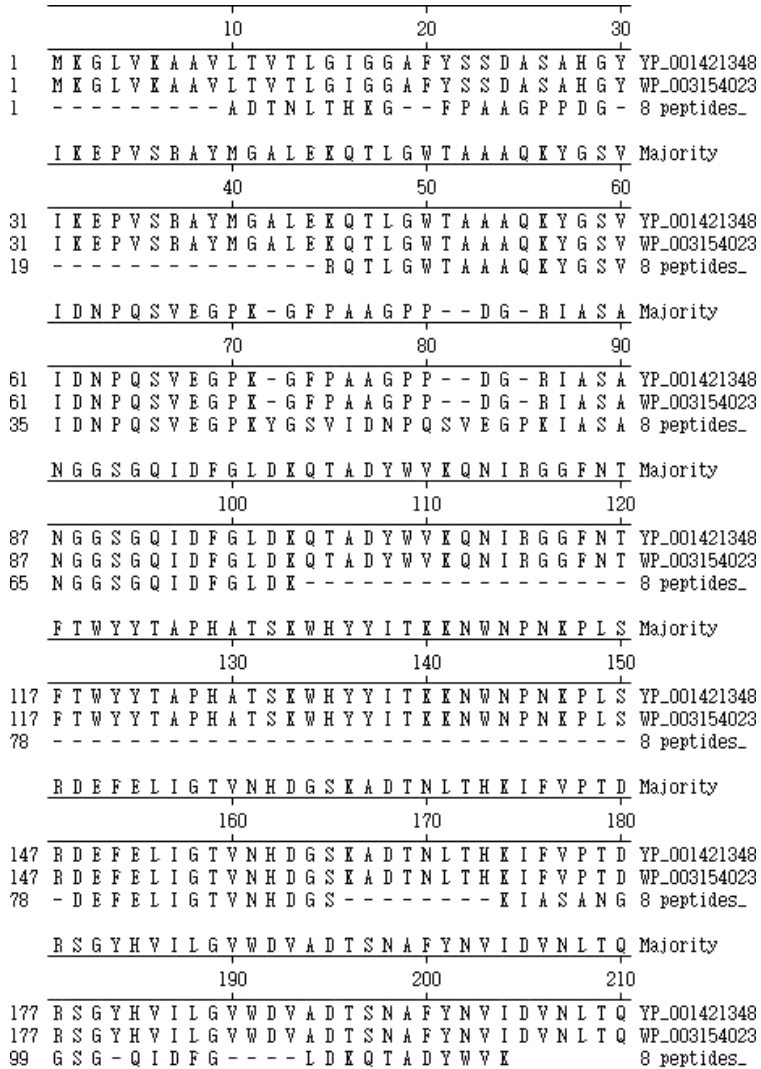

Fig. 4 Alignment of eight neutral identified peptides (8 peptides) with chitin-binding protein from Bacillus amyloliquefaciens FZB42 (YP_001 421 348) and chitin-binding protein from Bacillus (WP_003 154 023).
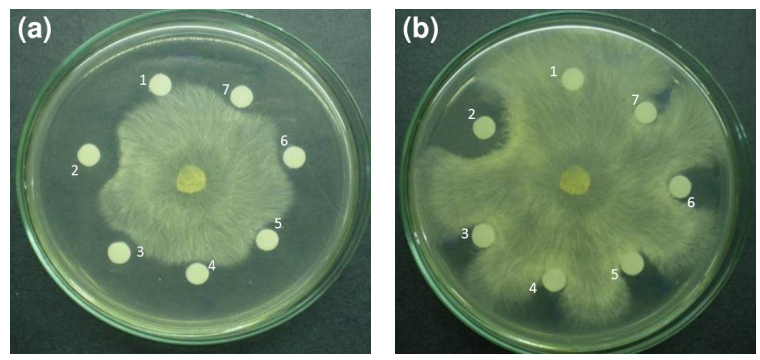

Fig. 5 Effects of temperature on the antifungal activity of the purified protein against (a) F. oxysporum and (b) R. solani. 1: control ( $20 \mu \mathrm{l}$ of $20 \mathrm{mM} \mathrm{Na}_{3} \mathrm{PO}_{4}$ buffer, $\mathrm{pH}$ 6.8); 2-6: samples treated at $80^{\circ} \mathrm{C}$ for $5-60 \mathrm{~min}$; 7 : sample treated at $100^{\circ} \mathrm{C}$ for $60 \mathrm{~min}$.

at $100^{\circ} \mathrm{C}$ for $60 \mathrm{~min}$. The results show that the antifungal protein retained activity when heated to $80^{\circ} \mathrm{C}$ and even to $100^{\circ} \mathrm{C}$ for $60 \mathrm{~min}$ (Fig. $5 \mathrm{a}$ and $5 \mathrm{~b}$ ). Proteinase K (EC 3.4.21.64) is a broad-spectrum 

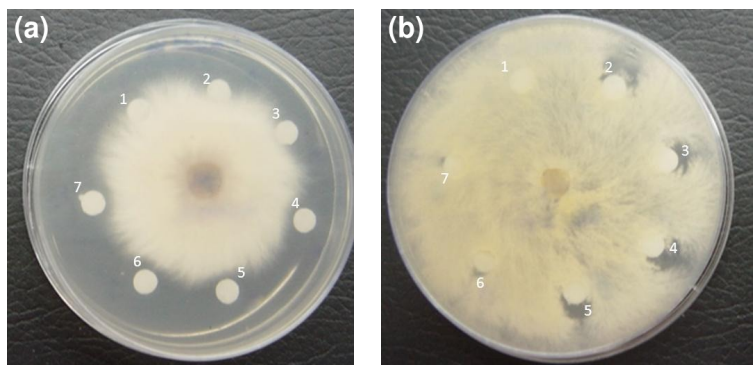

Fig. 6 Effect of proteinase K on antifungal activity of the purified protein against (a) F. oxysporum and (b) R. solani. 1: $20 \mathrm{mM} \mathrm{Na}_{3} \mathrm{PO}_{4}$ buffer, $\mathrm{pH} 6.8 ; 2-5$ : samples treated with proteinase $\mathrm{K}(0.5,1.0,2.0$, and $2.5 \mu \mathrm{g}$, respectively); 6: proteinase K $0.5 \mu \mathrm{g}$; 7: sample not treated with proteinase $\mathrm{K}$.

serine protease commonly used in molecular biology to digest proteins. Here, we incubated the purified protein with proteinase $\mathrm{K}$ at final concentrations between 0.5 and $2.5 \mu \mathrm{g} / \mathrm{ml}$ at $37^{\circ} \mathrm{C}$ for $60 \mathrm{~min}$. The data showed that proteinase $\mathrm{K}$ did not inhibit antifungal activity of the purified protein (Fig. 6a and $6 \mathrm{~b})$.

\section{DISCUSSION}

Fungal diseases are one of the most popular causes of major losses suffered by agricultural crops today. In fact, one in every eight crop plants, on average, will fail to yield because of fungal disease ${ }^{19}$. Using bacterial antagonist as a biological control agent against plant fungal pathogen has recently become a promising solution for the agriculture of many countries in the world.

From more than one hundred Bacillus strains isolated from different samples in Vietnam, B. subtilis XL62 was chosen to be examined for its antifungal activity against $F$. oxysporum and $R$. solani, two fungi that infect many important food crops. The results show that the crude supernatant of $B$. subtilis XL62 has a significant antifungal activity on both fungal pathogens. Our results are in agreement with those of Islam et al who reported the antifungal activity of an ethyl acetate extract $(2 \mathrm{mg} /$ well) of B. subtilis $\mathrm{C}$, which inhibited the growth of $R$. solani AG2-2(IV), R. solani AG1-1(A), R. solani AG-4, and F. oxysporum mycelia by $88 \%, 32 \%, 72 \%$, and $72 \%$, respectively ${ }^{1}$. In addition, Ali et al showed that a culture filtrate from Bacillus sp. RMB7 inhibited the growth of nine fungal phytopathogens by $>70 \%$ in vitro ${ }^{20}$. B. subtilis B29 shows antifungal activity against $F$ oxysporum, $R$. solani, $F$ moniliforme, and S. sclerotiorum, although F. oxysporum and R. solani showed the greatest sensitivity ${ }^{21}$.

To find out the element responsible for the antifungal activity of $B$. subtilis XL62, the crude supernatant of $B$. subtilis XL62 was precipitated by addition of $30-70 \%$ ammonium sulphate, and then was continuously purified using ion exchange chromatography on DEAE-cellulose and Biogel P100 chromatography. These methods are similar to those used by other studies ${ }^{22,23}$. Indeed, ion exchange chromatography on DEAE-cellulose, followed by Biogel P100 chromatography, has been used to extract other proteins with antifungal activity $^{24,25}$. In our study, the purified protein has activity against both $F$ oxysporum and $R$. solani (Fig. 3a and $3 \mathrm{~b}$ ) and a molecular weight of $\sim 22 \mathrm{kDa}$. The molecular weight of this antifungal protein was different from that of other antifungal proteins purified from $B$. subtilis. Liu et al extracted bacisubin from B. subtilis B916, which has a molecular weight of $41.9 \mathrm{kDa}$ and exhibits antifungal activity against F. oxysporum and R. solani ${ }^{25}$. Li et al extracted protein B29I from B. subtilis strain B29, which has a molecular weight of $42.9 \mathrm{kDa}$ and shows antifungal activity $^{21}$. Tan et al purified antifungal protein with molecular weight of $38 \mathrm{kDa}$ from B. subtilis $\mathrm{B} 25^{26}$. The difference in antifungal peptides produced by different strains of $B$. subtilis may be due to the fact that biosynthesis of antibiotics from microorganisms is often regulated by nutritional and environmental factors ${ }^{1}$. Using MALDI-TOF mass spectrometry to characterize the purified protein, we found that it is a chitin-binding protein. This result was in agreement with other reports that chitin-binding proteins play an important role in the protection of plants against pathogen infection ${ }^{27,28}$. The mechanisms against fungal attack of chitin-binding proteins was supposed to take part in degrading chitin and/or adhering to the chitinous surfaces of the host cells ${ }^{29,30}$.

Because Bacillus-derived compounds are the predominant class of antibiotics ${ }^{31}$, several studies examined the effects of heat, $\mathrm{pH}$, and proteolytic enzymes (proteinase $\mathrm{K}$ and trypsin) on the activity of antifungal compounds produced by Bacillus sp. In the present study, the thermal stability and the proteinase $\mathrm{K}$ resistance of the purified protein were also examined. The data showed that proteinase $\mathrm{K}$ did not inhibit antifungal activity (Fig. 6a and $6 \mathrm{~b})$. Our result was in agreement with some previous studies which reported that the antifungal compound was resistant to several proteolytic enzymes, including proteinase $\mathrm{E}$, proteinase $\mathrm{K}$, and chymotrypsin $^{32}$. Balouiri et $\mathrm{al}^{33}$ showed that the anti-candida activity of bioactive compounds pro- 
duced by Bacillus spp. was not affected by trypsin or proteinase $\mathrm{K}$. In the presence of proteinase $\mathrm{K}$, the inhibition zone reached $21.3 \pm 0.6 \mathrm{~mm}$, compared with $23.3 \pm 0.6 \mathrm{~mm}$ for the positive control ${ }^{33}$. The protease resistance ability of antifungal protein may be because they are hydrolysed into smaller peptides, which retain antifungal activity.

The purified protein is also quite thermostable as it retained activity when heated to $80^{\circ} \mathrm{C}$ and even to $100^{\circ} \mathrm{C}$ for $60 \mathrm{~min}$. This result was in agreement with previous studies such as that of Zhang et al. The purified novel protein, BTL, from Bacillus strain BTL2 from tobacco stems was also thermostable, retaining almost $100 \%$ activity when heated to $100^{\circ} \mathrm{C}$ for $15 \mathrm{~min}^{34}$. Chitarra et al reported that an antifungal compound produced by $B$. subtilis YM 10-20 was heat stable. The protein inhibited the growth of P. roqueforti after heating to $70^{\circ} \mathrm{C}$ or $100^{\circ} \mathrm{C}$ for $1 \mathrm{~h}^{32}$. The abovementioned result of MALDI-TOF, which indicated that the purified protein TOF was chitinbinding protein, may give us logical explanation for this thermal stability.

In conclusion, this study evaluated that the crude bacterial supernatant from B. subtilis XL62 has a significant antifungal activity against $F$ oxysporum and R. solani, two harmful pathogenic fungi. In addition, we successfully purified an antifungal protein from this supernatant. These results help to open the door for the B. subtilis XL62 to become a potential environmentally friendly agent to control plant fungal diseases.

Acknowledgements: This study was supported by the National Foundation for Science and Technology Development Vietnam (Nafosted), project 106.05-2012.35: "Screening, extraction, purification and structure analysis of some novel antagonistic compounds (or derivatives) against Fusarium and Rhizoctonia from Bacillus, Burkholderia, Pseudomonas and Serratia isolates in Vietnam", 2013-2015.

\section{REFERENCES}

1. Islam MR, Jeong YT, Lee YS, Song CH (2012) Isolation and identification of antifungal compounds from Bacillus subtilis C9 inhibiting the growth of plant pathogenic fungi. Mycobiology 40, 59-66.

2. Delcambe L, Peypoux F, Besson F, Guinand M, Michel G (1977) Structure of iturin and iturin-like substances. Biochem Soc Trans 5, 1122-4.

3. Stein T (2005) Bacillus subtilis antibiotics: structures, syntheses and specific functions. Mol Microbiol 56, 845-57.

4. Carrillo C, Teruel JA, Aranda FJ, Ortiz A (2003) Molecular mechanism of membrane permeabiliza- tion by the peptide antibiotic surfactin. Biochim Biophys Acta 1611, 91-7.

5. Peypoux F, Bonmatin JM, Wallach J (1999) Recent trends in the biochemistry of surfactin. Appl Microbiol Biotechnol 51, 553-63.

6. Loeffler W, Tschen JSM, Vanittanakom N, Kulger M, Knorpp E, Hsieh TF, Wu TG (1986) Antifungal effects of bacilysin and fengycin from Bacillus subtilis F293. A comparison with activities of other Bacillus antibiotics. J Phytopathol 115, 204-13.

7. Peypoux F, Besson F, Michel G (1980) Characterization of a new antibiotic of iturin group bacilloycin $\mathrm{D}$. $J$ Antibiot 33, 1146-9.

8. Peypoux F, Pommier MT, Marion D, Ptak M, Das BC, Michel G (1986) Revised structure of mycosubtilin, a lipidolipid antibiotic from B. subtilis. J Antibiot 39, 636-41.

9. Majumdar SK, Bose SK (1960) Isolation and homogeneity of mycobacillin. Arch Biochem Biophys 90, 154-8.

10. Sengupta S, Banerjee AB, Bose SK (1971) $\gamma$-Glutamyl and D- or L-peptide linkages in mycobacillin, a cyclic peptide antibiotic. Biochem $J$ 121, 839-46.

11. Ting SY, Mah SW, Tee CS (2010) Identification of volatile metabolites from fungal endophytes with biocontrol potential towards Fusarium oxysporum F. sp. cubense race 4. Am J Agr Biol Sci 5, 177-82.

12. Chaurasia B, Pandey A, Palni LMS, Trivedi P, Kumar B, Colvin N (2005) Diffusible and volatile compounds produced by an antagonistic Bacillus subtilis strain cause structural deformations in pathogenic fungi in vitro. Microbiol Res 160, 75-81.

13. Weller DM (1988) Biological control of soilborne plant pathogens in the rhizosphere with bacteria. Annu Rev Phytopathol 26, 379-407.

14. Huber J, Bochow H, Junge H (1987) Selektion und biotechnische Herstellung von Kulturlösungen mikrobieller Antagonisten zur Unterdrückung phytopathogener Bodenpilze. J Basic Microbiol 27, 497-503.

15. Laemmli UK (1970) Clevage of structure proteins during the assembly of the head of bacteriophage T4. Nature 227, 680-5.

16. Bassam BJ, Caetano-Anollés G, Gresshoff PM (1991) Fast and sensitive silver staining of DNA in polyacrylamide gels. Anal Biochem 196, 80-3.

17. Bradford MM (1976) A rapid and sensitive method for the quantification of microgram quantities of protein utilizing the principle of protein-dye binding. Anal Biochem 72, 248-54.

18. Bringans S, Eriksen S, Kendrick T, Gopalakrishnakone P, Livk A, Lock R, Lipscombe R (2008) Proteomic analysis of the venom of Heterometrus longimanus (Asian black scorpion). Proteomics 8, 1081-96.

19. Oerke EC (2006) Crop losses to pests. J Agr Sci 144, 31-43. 
20. Ali S, Hameed S, Imran A, Iqbal M, Lazarovits G (2014) Genetic, physiological and biochemical characterization of Bacillus sp. strain RMB7 exhibiting plant growth promoting and broad spectrum antifungal activities. Microb Cell Fact 13, 144.

21. Li J, Yang Q, Zhao L, Zhang S, Wang Y, Zhao X (2009) Purification and characterization of a novel antifungal protein from Bacillus subtilis strain B29. $J$ Zhejiang Univ Sci B 10, 264-72.

22. Wang H, Ng TB (2002) Isolation of cicadin, a novel and potent antifungal peptide from juvenile cicadas. Peptides 23, 7-11.

23. Ngai PHK, Zhao Z, Ng TB (2005) Agrocybin, an antifungal peptide from the edible mushroom Agrocybe cylindracea. Peptides 26, 191-6.

24. Lam YW, Wang HX, Ng TB (2000) A robust cysteinedeficient chitinase-like antifungal protein from inner shoots of the edible chive Allium tuberosum. Biochem Biophys Res Comm 279, 74-80.

25. Liu Y, Chen Z, Ng TB, Zhang J, Zhou M, Song F, Lu F, Liu Y (2007) Bacisubin, an antifungal protein with ribonuclease and hemagglutinating activities from Bacillus subtilis strain B-916. Peptides 28, 553-9.

26. Tan Z, Lin B, Zhang R (2013) A novel antifungal protein of Bacillus subtilis B25. SpringerPlus 2, 543-9.

27. Nielsen KK, Nielsen JE, Madrid SM, Mikkelsen JD (1997) Characterization of a new antifungal chitinbinding peptide from sugar beet leaves. Plant Physiol 113, 83-91.

28. Bormann C, Baier D, Horr I, Raps C, Berger J, Jung G (1999) Characterization of a novel, antifungal, chitin-binding protein from Streptomyces tendae Tu901 that interferes with growth polarity. J Bacteriol 181, 7421-9.

29. Vaaje-Kolstad G, Horn SJ, van Aalten DMF, Synstad B, Eijsink VGH (2005) The non-catalytic chitin-binding protein CBP21 from Serratia marcescens is essential for chitin degradation. $J$ Biol Chem 280, 28492-7.

30. Bhattacharya D, Nagpure A, Gupta RK (2007) Bacterial chitinases: properties and potential. Crit Rev Biotechnol 27, 21-8.

31. Sansinenea E, Ortiz A (2011) Secondary metabolites of soil Bacillus spp. Biotechnol Lett 33, 1523-38.

32. Chitarra GS, Breeuwer P, Nout MJR, van Aelst AC, Rombouts FM, Abee T (2003) An antifungal compound produced by Bacillus subtilis YM 10-20 inhibits germination of Penicillium roqueforti conidiospores. J Appl Microbiol 94, 159-66.

33. Balouiri M, Bouhdid S, Harki EH, Sadiki M, Ouedrhiri W, Ibnsouda SK (2015) Antifungal activity of Bacillus spp. isolated from Calotropis procera Ait. rhizosphere against Candida albicans. Asian J Pharmaceut Clin Res 8, 213-7.

34. Zhang B, Xie C, Yang X (2008) A novel small antifungal peptide from Bacillus strain B-TL2 isolated from tobacco stems. Peptides 29, 350-5. 